\title{
The Ultrastructure of Cartilage Formation from Neonatal Skeletal Muscle in vitro*
}

\author{
Yasuyuki HorisaKa $^{1}$, Yasuo OKamoto ${ }^{1}$, Naoyuki Matsumoto ${ }^{1}$, Yoshiyuki Yoshimura ${ }^{3}$, \\ Jun KAWADA ${ }^{3}$, Kikuji YAMASHITA ${ }^{2}$ and Tomomichi TAKagI ${ }^{2}$
}

Departments of Removable Prosthodontics ${ }^{1}$ and Anatomy ${ }^{2}$, School of Dentistry, and the Department of Biochemistry ${ }^{3}$, Faculty of Pharmaceutical Sciences, Tokushima University, Tokushima, Japan

Received September 17, 1990

Summary. Histological changes in cultured neonatal skeletal muscle tissue at the early stage of cartilage induction by syngeneic insoluble bone matrix gelatin (BMG) containing bone morphogenetic protein were examined by light and electron microscopy. Minced skeletal muscle was cultured on hemicylindrical pieces of BMG for 14 days. Chondroblasts first appeared in the crevices of the BMG on Day 7 of the culture, and cartilage tissue was seen to fill the crevices completely by Day 10. The main findings in this work are as follows: 1) the activation of satellite cells and necrosis of myonuclei; 2) the migration of satellite cells from the basement membrane; 3 ) fibroblasts with increased numbers of organelles between degenerated muscle fibers closely resembling the migratory satellite cells; 4) the migration of the spindle-shaped cells into the crevices of the BMG; and 5) change of the spindle-shaped cells to chondroblasts.

These findings suggest that neonatal skeletal muscles, which appear more mature than embryonic muscles, also have a chondrogenetic potential when grown on $\mathrm{BMG}$, and that chondroblasts originate from the spindleshaped cells which are thought to result from migratory satellite cells as well as fibroblasts.

It has been established that intramuscular implantation of demineralized bone matrix induces heterotopic osteogenesis, and this osteoinductive factor was named the bone morphogenetic protein (BMG) (URIST, 1965). Since then, there have been many studies on bone induction in vivo (URIST et al., 1973, 1984; AMitAni and NAKATA, 1975; REDDI and ANDERSON, 1976; NilsEN, 1977, 1980; SAMPATH et al., 1987;
Wozney et al., 1988; BENTZ et al., 1989; WANG et al., 1990; OKAмото et al., 1991), and in vitro (MogAmi and URIST, 1974; NATHANSON et al., 1978; URIST et al., 1978; NATHANSON and HAY, 1980; LANDESMAN and REDDI, 1986; NATHANSON, 1986; SOMERMAN et al., 1987; KAWAMURA and URIST, 1988; VUKICEVIC et al., 1989, 1990; KUKITA et al., 1990), and on the extraction of BMP from both the bone matrices (URIST et al., 1984; SAMPATH et al., 1987; WoZNEY et al., 1988; BENTZ et al., 1989; LUYTEN et al., 1989; WANG et al., 1990) and osteosarcomas (TAKAOKA et al., 1981). Recently, WozNEY and his co-workers (1988) have reported on three osteoinductive polypeptides and their amino acid sequences deduced from their cDNA clones. There are, however, only three reports on the transdifferentiation of muscle using BMP (NATHANSON et al., 1978; NATHANSON and HAY, 1980; NATHANSON, 1986). These workers demonstrated that, in addition to embryonic mesenchymal cells, both myoblasts and fibroblasts have a chondrogenetic potential when cultured on insoluble bone matrix gelatin (BMG). Recently, Окамото and co-workers (1991) reported that intramuscular implantation of BMG caused the conspicuous disappearance of the basement membrane of muscle fibers, and that its disappearance played an important role in the osteogenesis induced by the BMG.

In this study, we cultured neonatal skeletal muscle on BMG, and examined histological changes in the muscle tissue, especially those of the basement membrane and satellite cells in order to discuss the transdifferentiation of muscle satellite cells.

\footnotetext{
*This work was supported in part by a Grant-in-Aid for Scientific Research (No. 02954161) from the Ministry of Education, Science and Culture, Japan.
} 


\section{MATERIALS AND METHODS}

BMG was prepared by the method of NoGAmI and URIST (1974). Pieces of diaphyseal bone from the femur and tibia were obtained from 12-week-old Sprague-Dawley strain rats. Cylindrical pieces of bone were then extracted with chloroform-methanol $(1: 1, \mathrm{v} / \mathrm{v})$ to remove the lipid, demineralized in $0.6 \mathrm{~N}$ $\mathrm{HCl}$ and extracted with $2.0 \mathrm{M} \mathrm{CaCl}_{2}, 0.5 \mathrm{M}$ EDTA, 8.0 $\mathrm{M} \mathrm{LiCl}$ and $\mathrm{H}_{2} \mathrm{O}$ to remove soluble proteins. The BMG obtained by these treatments was cut into hemicylinders ( $8 \mathrm{~mm}$ : length), lyophilized and use for culturing. BMG heated at $150^{\circ} \mathrm{C}$ for $30 \mathrm{~min}$ was used as a control.

The biceps femoris muscles and triceps surae muscles of neonatal (0 day) Sprague-Dawley strain

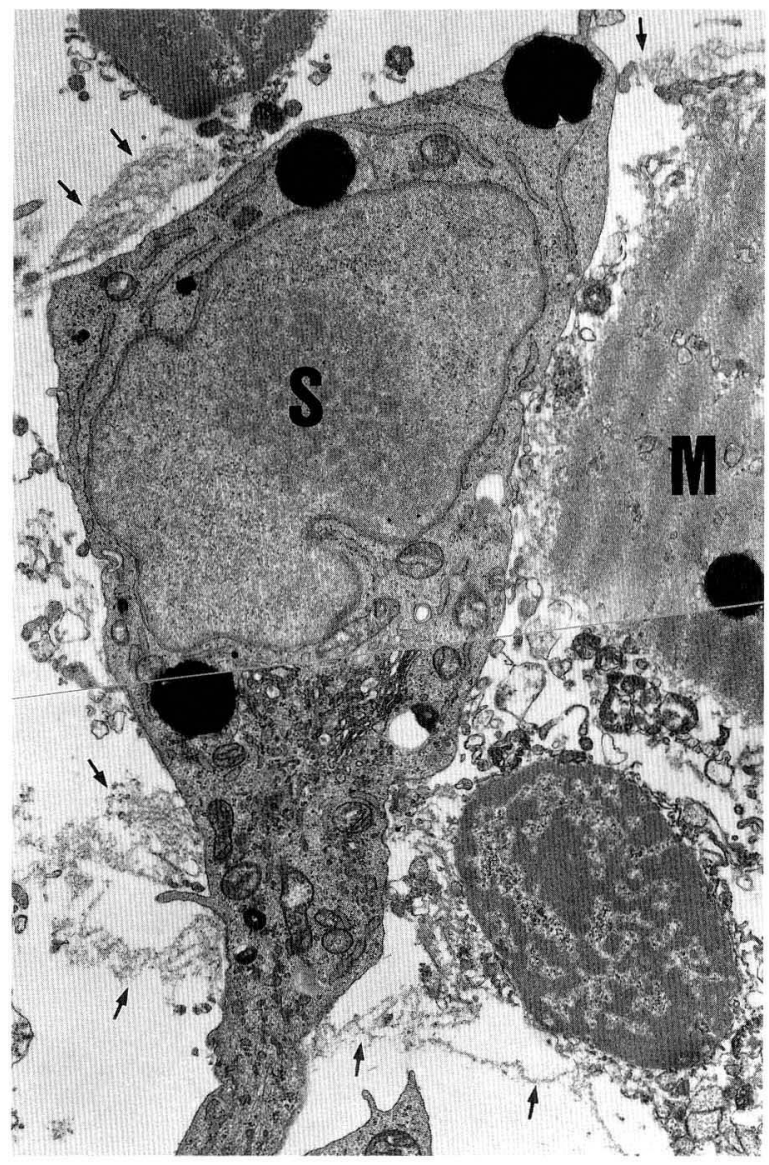

Fig. 1. Day 1 in the culture. Electron micrograph of a muscle satellite cell $(S)$ and degenerated muscle fiber $(M)$. The satellite cell has a pale nucleus and well-developed organelles with dense bodies. Its cell processes protrude from the basement membrane (arrows). $\times 7,000$ rats were transferred to ice-cold Hanks' balanced salt solution. Adherent dermis, vascular and nervous tissue were removed and the muscle tissue was placed in an ice-cold culture medium, and sectioned.

The hemicylindrical BMG were transversely cut halfway through at $1 \mathrm{~mm}$ intervals, and the minced muscle (15 mg) was placed on it. These explants were placed on a stainless steel wire grid in the center of a $35 \mathrm{~mm}$ culture dish.

The culture medium consisted of $90 \% \alpha$-MEM (Flow Laboratory) and 10\% fetal calf serum, supplemented with $0.2 \%$ sodium bicarbonate and $60 \mu \mathrm{g} / \mathrm{ml}$ Kanamycin sulfate. Cultures were maintained at $37^{\circ} \mathrm{C}$ under $5 \% \mathrm{CO}_{2}$ in air. Half the explant was exposed to the atmosphere and three-quarters of the culture medium was renewed every two days.

Muscle tissues in situ and explants on Days 1, 3, 5, 7,10 and 14 of the culture were fixed in 10\% formalin in neutral phosphate buffered saline, dehydrated in an ethanol series and embedded in Technovit 7100 (Kulzer \& Co. GmbH, Friedrichsdorf, FRG). The blocks were sectioned at $5 \mu \mathrm{m}$ thickness and stained with hematoxylin and eosin, and toluidine blue. For electron microscopy, the specimens were fixed in $2.5 \%$ glutaraldehyde in $0.1 \mathrm{M} \mathrm{PBS}(\mathrm{pH} 7.4)$ at $4^{\circ} \mathrm{C}$ for $1 \mathrm{~h}$ and postfixed in 1\% $\mathrm{OsO}_{4}$ (Nacalai Tesque, Kyoto, Japan) in $0.1 \%$ PBS (pH 7.4) at $4^{\circ} \mathrm{C}$ for $1 \mathrm{~h}$. They were then dehydrated, embedded in Epon 812 (TAAB Laboratories, Berkshire, England) and sectioned with an ultramicrotome. Sections of $1 \mu \mathrm{m}$ thickness were stained with toluidine blue and examined by light microscopy. Ultrathin sections were stained with both uranyl acetate and lead citrate and examined in an electron microscope (H-800, Hitachi Ltd., Tokyo, Japan).

\section{RESULTS}

The neonatal rat skeletal muscles used in the experiments consisted of clusters of slender muscle fibers and a broad, apparently empty perimysium containing a few cells with poorly developed cytoplasm, nerves and immature vessels. The muscle fibers had pale round nuclei with prominent nucleoli in their periphery. Their cytoplasm contained immature myofibrils which did not fill the cytoplasm, together with mitochondria and free ribosomes among the myofibrils. Beside the muscle fibers, a few myotubes and satellite cells were also seen. These satellite cells had heterochromatic nuclei, few detectable cell organelles and little cytoplasm. The number of satellite cells was more than that of adults. The basement membrane was well-developed and appeared as a 
continuous thin line. Two types of fibroblasts were seen in the perimysium. One type was pale and fusiform with euchromatic nuclei and poorly developed rough endoplasmic reticulum; the other type was round or fusiform with round heterochromatic nuclei, and free ribosomes and polysomes in the cytoplasm. The latter type was the more numerous. The basement membrane of vessels was clearly seen.

On Day 1 in the culture, muscle fibers degenerated and some figures of cell division between them were seen. Muscle fibers contracted into round or wavy masses. The myofibril organization was then lost and the myonuclei became heterochromatic and pyknotic. The basement membranes of muscle fibers became slackened and rumpled, and in some places disappeared. Most of the satellite cells had a pale, partially indented nucleus and long slender cisterns of rough endoplasmic reticulum, Golgi lamellae, mitochondria, free ribosomes and a few dense bodies. These dense bodies were spherical ( $1 \mu \mathrm{m}$ in diameter) with homogeneous contents. Some of these satellite cells extended cytoplasmic processes from the tear in the basement membrane (Fig. 1). Between the degenerated muscle fibers, spindle-shaped cells with pale nuclei were frequently seen, instead of the two types of fibroblasts with poorly developed cytoplasm observed in situ (Fig. 2). Their cytoplasm contained Golgi vacuoles, free ribosomes, sparse long cisterns of rough endoplasmic reticulum and several dense bodies. These cells resembled the protruded satellite cells in the shape of their nuclei and in their cytoplasmic organelles. The basement membrane of vessels also became slackened and organelles increased in pericytes.

On Day 3 in the culture, muscle degeneratjon progressed and the division of spindle-shaped cells between them increased. These spindle-shaped cells were thinner than on Day 1. The myonuclei in the muscle fibers disappeared and macrophages were

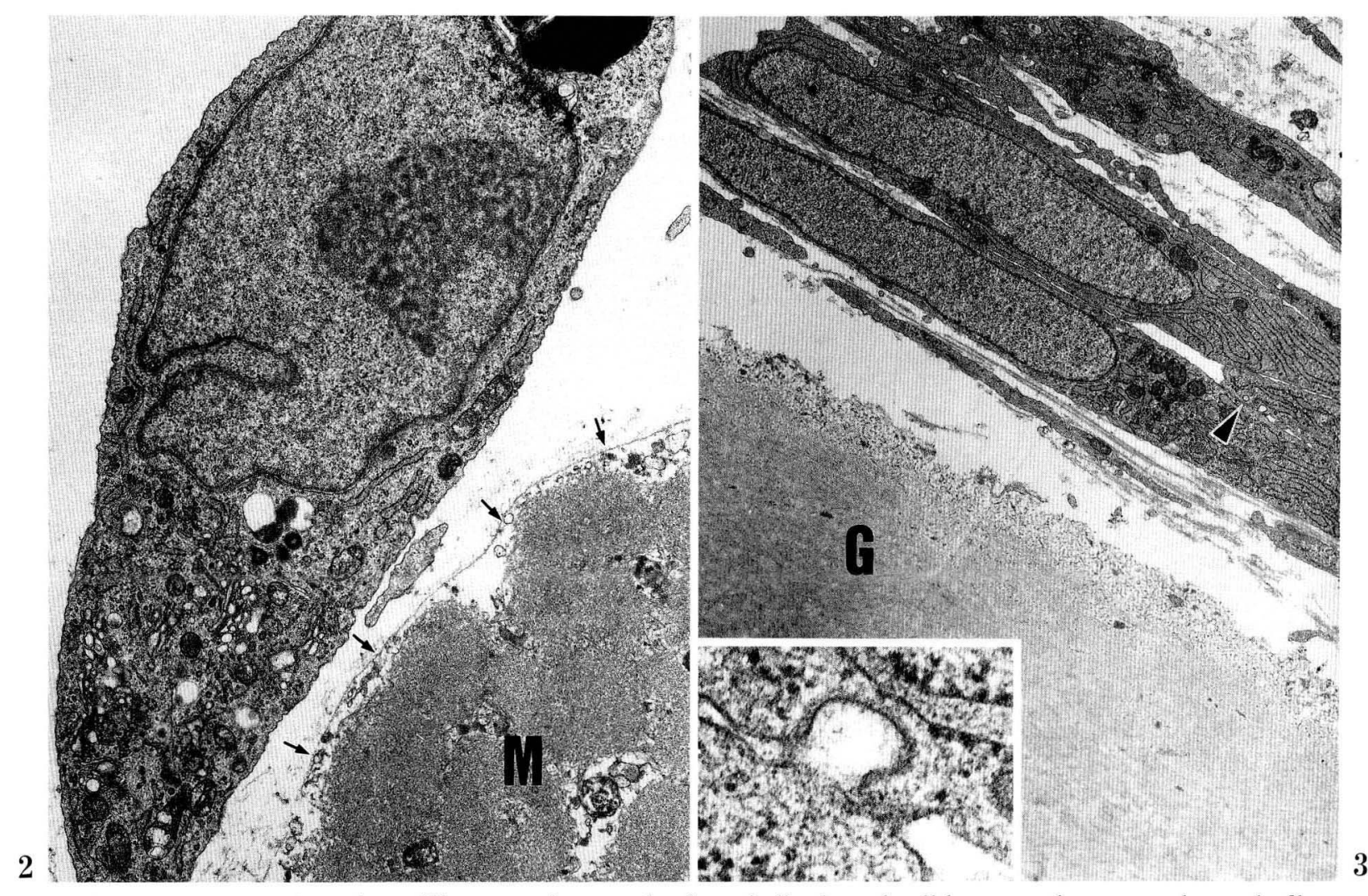

Fig. 2. Day 1 in the culture. Electron micrograph of a spindle-shaped cell between degenerated muscle fibers $(M)$. The cell has a pale, indented nucleus, Golgi vacuoles, free ribosomes and dense bodies, and resembles the cell in Figure 1. Arrows show the basement membrane. $\times 8,800$

Fig. 3. Day 3 in the culture. Electron micrograph of a spindle-shaped cells with a smooth surface on the surface of BMG $(G)$. These cells reach back to themselves with cytoplasmic processes (arrowhead). $\times 5,600$. The inset shows a high magnification of the relation of the spindle-shaped cells. $\times 60,000$ 

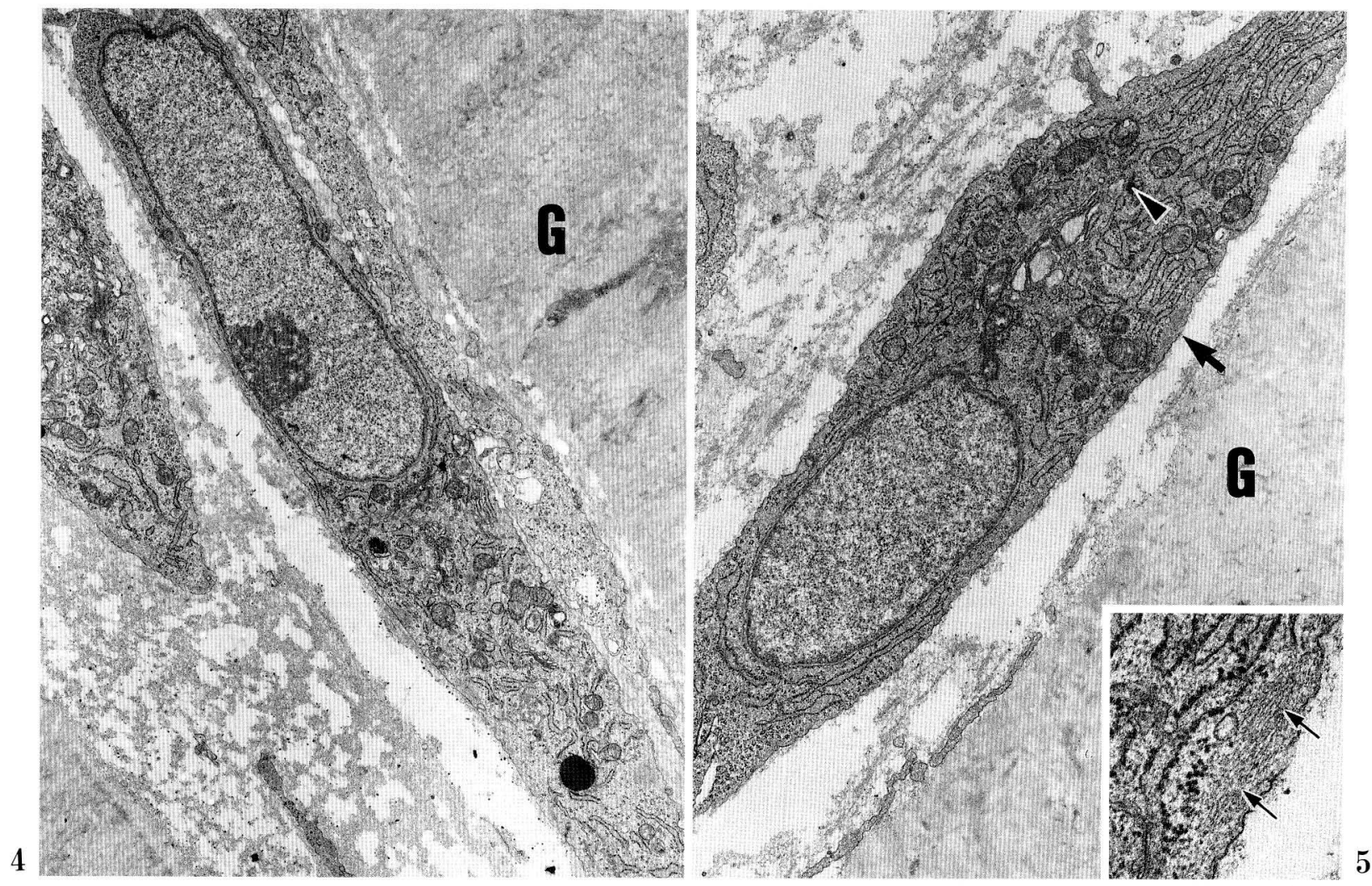

Fig. 4. Day 5 in the culture. Electron micrograph of a spindle-shaped cell in a crevice of BMG $(G)$. The nucleus/ cytoplasm ratio is smaller than that in Figure 3 and the cell contains considerably developed Golgi lamellae and dense bodies. $\times 6,400$

Fig. 5. Day 5 in the culture. Electron micrograph of a slightly round-shaped cell in a crevice of the BMG $(G)$. The cytoplasm contains a well-developed rough endoplasmic reticulum, prominent Golgi apparatus, dense bodies (arrowhead) and fine filaments (arrow). $\times 7,500$. The inset shows a bundle of fine filaments (arrows) at the cell surface along the BMG. $\times 33,000$

seen surrounding collapsed muscle fibers. Spindleshaped cells formed layers on the surface of the $\mathrm{BMG}$, and reached back to themselves with cytoplasmic processes. Some of these cells were clustered at the entrances of crevices of the BMG; these cells were $25 \mu \mathrm{m}$ in length and $5 \mu \mathrm{m}$ in diameter. The eccentric elliptical or round nuclei were relatively pale and had prominent nucleoli. Their cytoplasm contained somewhat well-developed cisternae of the rough endoplasmic reticulum, Golgi vacuoles, and dense bodies (Fig. 3). As the basement membrane of muscle fibers was folded and had partly disappeared, some muscle fibers were exposed without a basement membrane. Spindle-shaped cells also became scattered between the muscle fibers. The satellite cells could not be distinguished from the spindle-shaped cells.

On Day 5 in the culture, numerous macrophages appeared around the degenerating muscle fibers.
They had a partially collapsed dark nucleus, and many dense bodies and vacuoles. They extended many processes to the degenerating muscle fibers and phagocytized the remnants of fibers. The crevices contained many spindle-shaped cells with somewhat developed Golgi lamellae along the BMG (Fig. 4). The nucleus/cytoplasm ratio was smaller than those in Figure 3. There were also slightly round-shaped cells in the crevices (Fig. 5). These cells contained welldeveloped rough endoplasmic reticulum, prominent Golgi apparatus, dense bodies, vacuoles and bundles of fine filaments in the cytoplasm (Fig. 5 inset). Cell death and cell division were rarely observed in the explants. At the top of the explants, several layers of spindle-shaped cells were seen. These cells had large, pale, eccentric nuclei with prominent nucleoli and cytoplasm containing a well-developed rough endoplasmic reticulum, Golgi apparatus and filament bundles. 

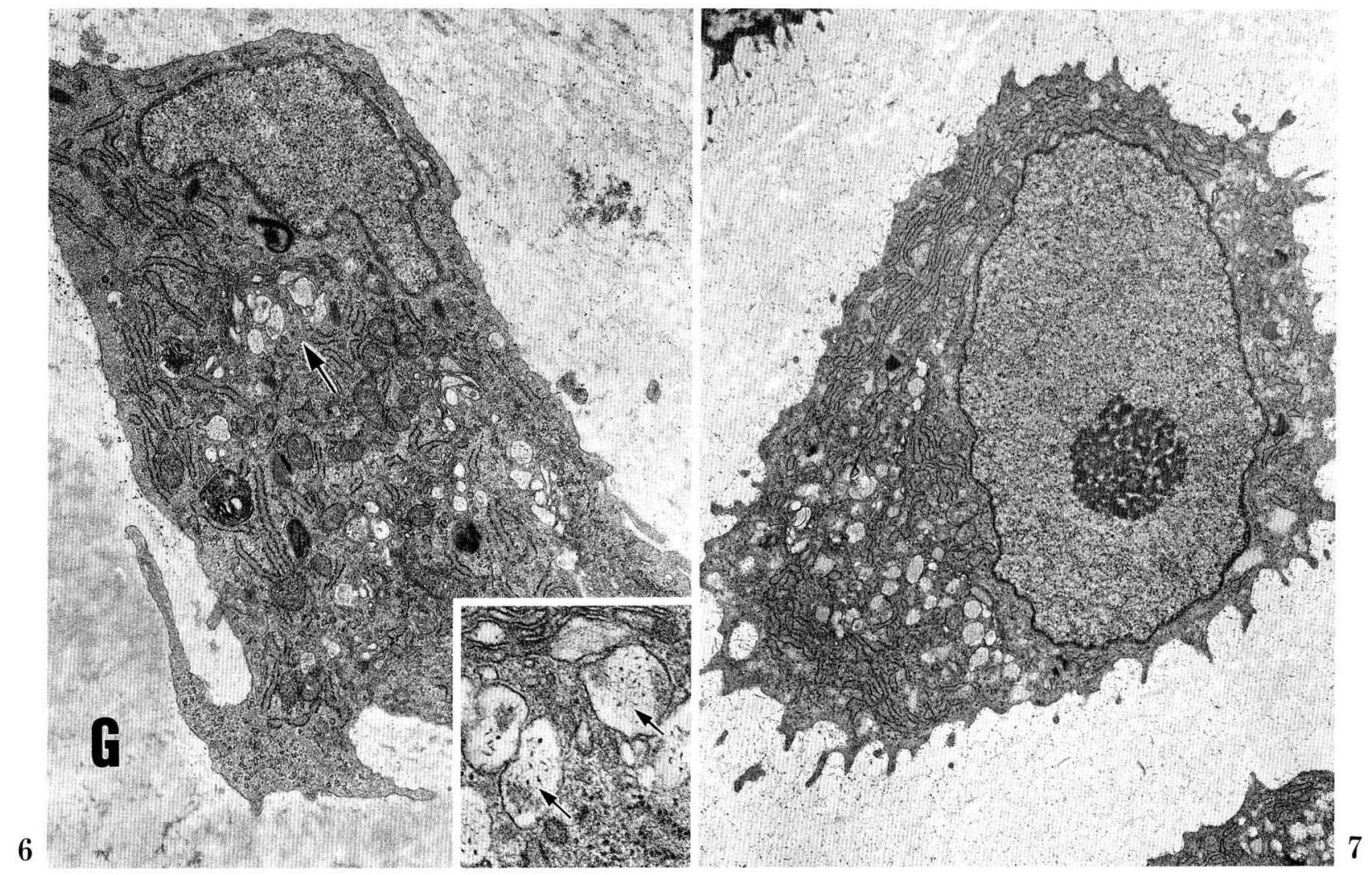

Fig. 6. Day 7 in the culture. Electron micrograph of a spindle-shaped cell in the upper part of a crevice. It contacts with the BMG $(G)$, and has a Golgi apparatus and vacuoles $($ arrow $) . \times 10,000$. The inset shows vacuoles containing many filamentous structures (arrows). $\times 30,000$

Fig. 7. Day 7 in the culture. Electron micrograph of an oval-shaped chondroblast in the lower part of a crevice. The cell has a large pale nucleus and its surface is irregular. The cytoplasm contains a well-developed rough endoplasmic reticulum and many vacuoles. $\times 6,700$

On Day 7 in the culture, the number of collapsed muscles decreased, but macrophages were seen around them. Spindle-shaped cells at the top of the explants moved to the underside of the BMG. In two of three cases, a few oval-shaped chondroblasts similar to the spindle-shaped cells were seen at the bottom of the crevices (Figs. 6, 7). The matrix around the chondroblasts stained metachromatically with toluidine blue. These chondroblasts were irregular in contour and had large pale nuclei with prominent basophilic nucleoli (Fig. 7). Their cytoplasms contained welldeveloped rough endoplasmic reticulum, Golgi apparatus, free ribosomes, lysosomes and vacuoles (Fig. 6 inset); many short processes were seen on their cell surface. The matrices near spindle-shaped cells in the crevices also stained weakly.

On Day 10 in the culture, the cartilage filled the crevices completely (Fig. 8). Some cartilage covered the surface of the BMG and contained muscle rem- nants. Sparse fibrous connective tissue mainly containing macrophages, with a few spindle-shaped cells and a few muscle remnants, covered both the $\mathrm{BMG}$ and the cartilage.

On Day 14 in the culture, the maturation of chondrocytes was seen at the bottoms of the crevices. These chondrocytes had pale, eccentrically located nuclei and prominent nucleoli (Fig. 9). Their cytoplasm contained extensive rough endoplasmic reticulum, Golgi apparatus and many vacuoles. The chondrocytes were surrounded by an abundant extracellular matrix.

On the other hand, heat-treated BMG induced no cartilage throughout the culture period.

On Day 1 in the culture, muscle fibers degenerated and only a slight division of the cells between them was seen. Myonuclei became heterochromatic and pyknotic. Almost all of the basement membrane around the muscle fibers appeared continuous and the 


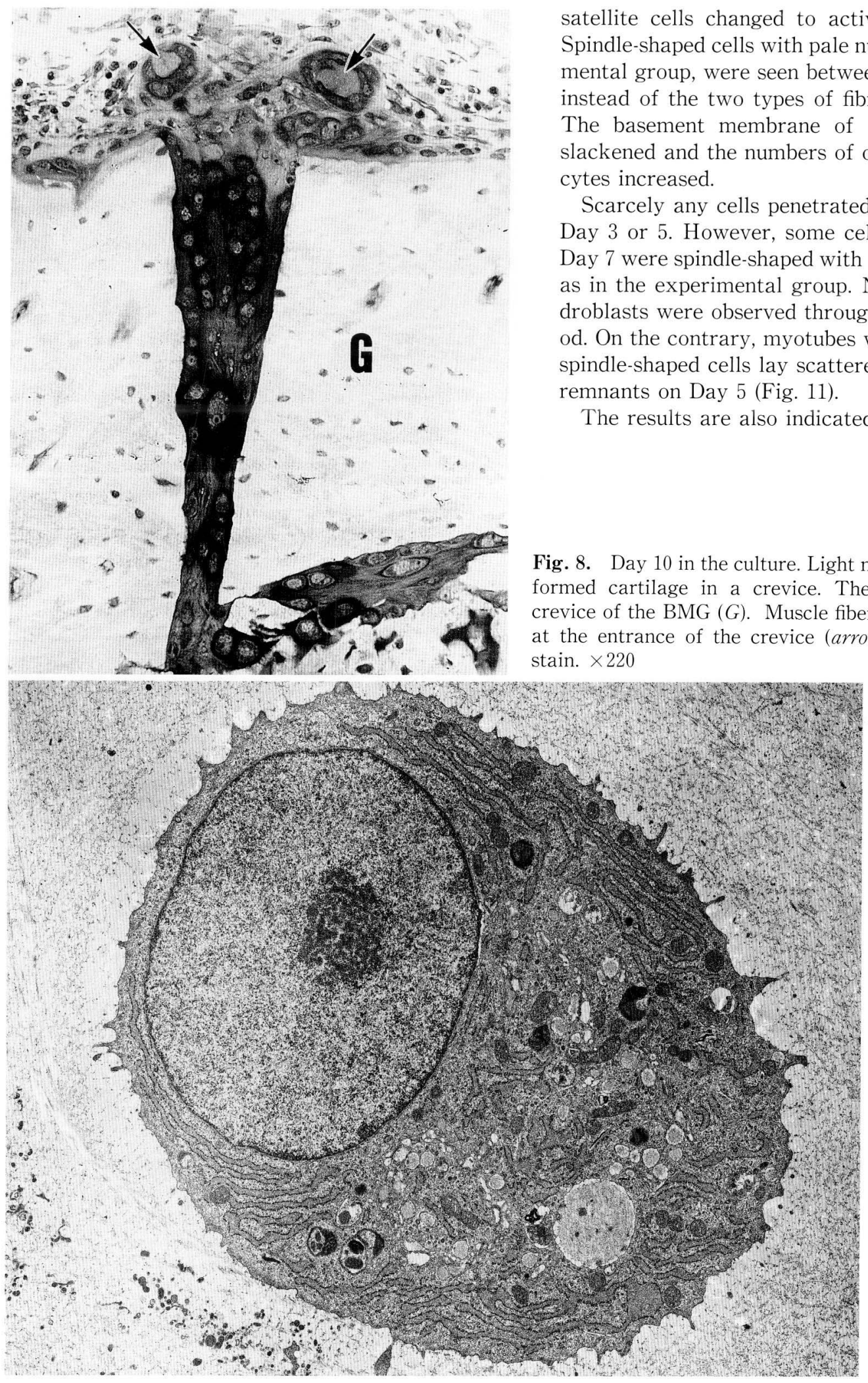

Fig. 9. Day 14 in the culture. Electron micrograph of a round chondrocyte deep in a crevice. Its pale nucleus is eccentric and its cytoplasm contains an extensive rough endoplasmic reticulum, large Golgi apparatus and many vacuoles. Note the abundant extracellular matrix. $\times 9,100$ 


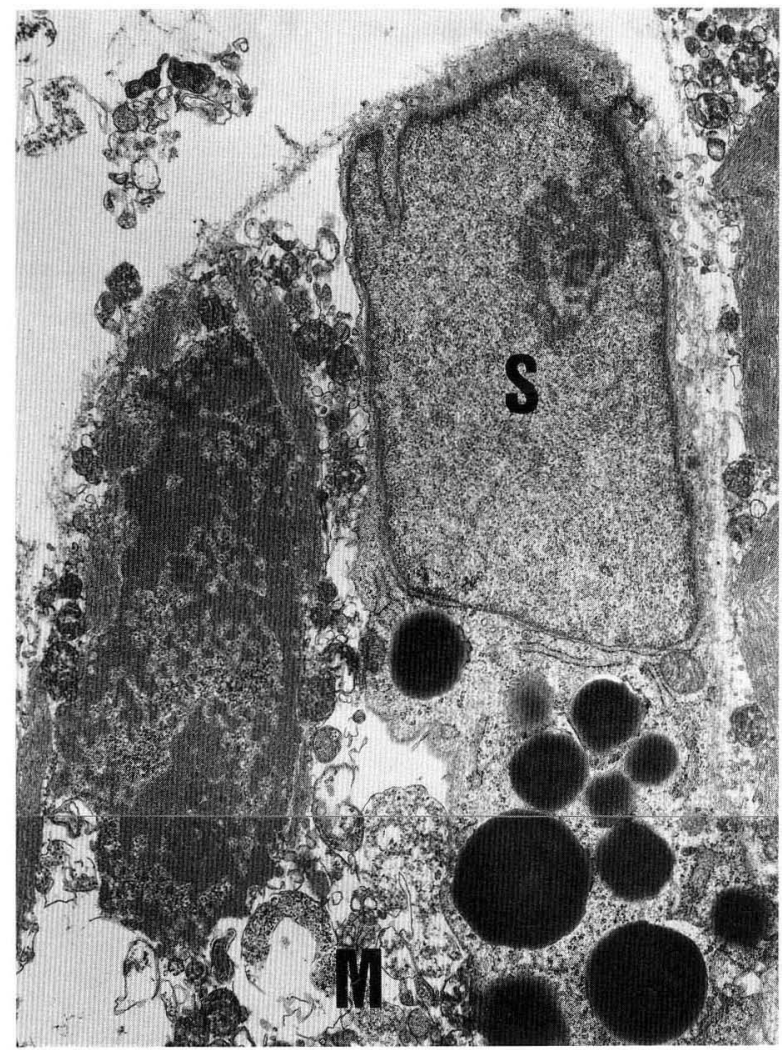

Fig. 10. Day 1 in the culture. Electron micrograph of a muscle satellite cell $(S)$ and degenerated muscle fiber $(M)$ in a control group. The satellite cells have changed to an activated state. $\times 6,500$

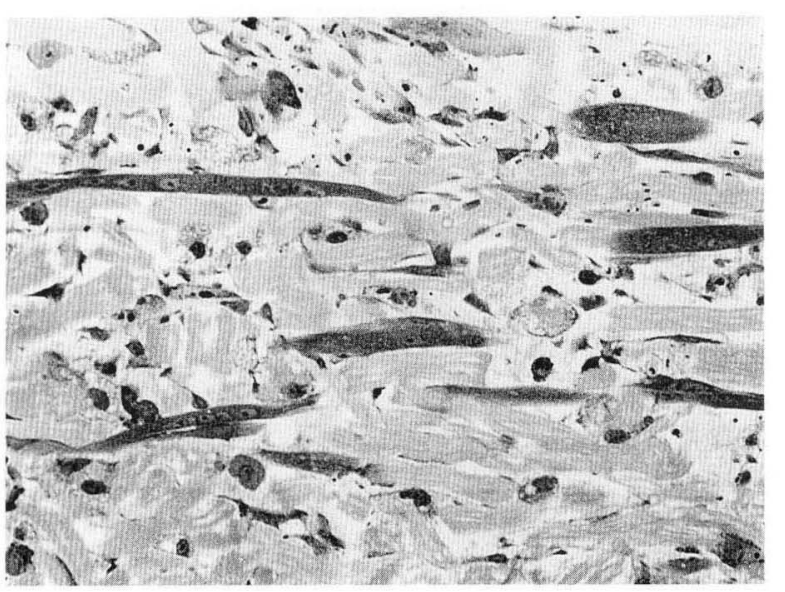

Fig. 11. Day 5 in the culture. Light micrograph of myotubes around muscle remnants in a control group. Several nuclei are seen in the myotube. Toluidine blue stain. $\times 490$

Table 1. Incidences of cartilage formation after various days of culturing

\begin{tabular}{lcccccc}
\hline & \multicolumn{6}{c}{ Days of culture } \\
\cline { 2 - 7 } & 1 & 3 & 5 & 7 & 10 & 14 \\
\hline Experimental & $0 / 3$ & $0 / 3$ & $0 / 3$ & $2 / 3$ & $3 / 3$ & $3 / 3$ \\
Control & $0 / 3$ & $0 / 3$ & $0 / 3$ & $0 / 3$ & $0 / 3$ & $0 / 3$ \\
\hline
\end{tabular}

\section{DISCUSSION}

In this report, we first observed the muscle degeneration and the increase in the number of mononuclear cells between them. After culturing for 3 to 5 days, spindle-shaped cells penetrated into the crevices of BMG. On Day 5, the organelles in these cells increased, and by Day 7, chondroblasts appeared.

NATHANSON and co-workers (1978, 1980, 1986) observed cartilage differentiation from embryonic skeletal muscle containing myoblasts, fibroblasts and myotubes. The tissues they examined were embryonic, and so contained various undifferentiated cell types, with the basement membrane around the myotubes not distinct. Moreover, no satellite cells were observed. The structure of skeletal muscle differs between the embryonic and neonatal periods, as neonatal skeletal muscle consists of differentiated muscle fibers with a complete basement membrane (Kelly and ZACK, 1969; Ontell, 1977; Ontell and
KOZEKA, 1984). In addition, a few myotubes and many satellite cells are present in the basement membrane (CAMPION, 1984).

In this report, we observed the partial disappearance of the basement membrane around the muscle fibers on Day 1 of the culture (Fig. 1). The disappearance of the basement membrane after implantation of BMG into skeletal muscle has been reported by OKAмото et al. (1991). In the present report, the disappearance of the basement membrane in the experimental group seemed to be due not only to mincing the muscle before its culture but also to the activated satellite cells that migrated from the basement membrane. Because most of the basement membrane remained intact in the minced tissue (SNOw, 1977a, b), no death of satellite cells was observed, cell processes from the activated satellite cells protruded outside the basement membrane, and 
these cells looking like the spindle-shaped cells between the degenerated muscle fibers on Day 1 (Fig. $1,2)$.

The number of spindle-shaped cells increased by Day 3; these cells migrated into the crevices of the BMG and differentiated in the experimental group. Little penetration of spindle-shaped cells into the crevices of the BMG was seen in the control group. These cells presumably migrated into the crevice as a result of the effect of BMP in the BMG (LANDESMAN and REDDI, 1986). Also, the spindle-shaped cells may represent one stage in phenotypic alteration (LOPASHOV, 1977; NATHANSON and HAY, 1980; NATHANSON, 1986). Moreover, chondroblasts seemed to originate from the satellite cells judging from the following observations and reports: 1) satellite cells have dense bodies like the spindle-shaped cells (Figs. 1,2);2) residual muscle fibers were seen near the crevices (Fig. 8); 3) satellite cells migrate from the basement membrane (Lipton and Schultz, 1979; MALTin et al., 1983; Maltin, 1986; Hughes and Blau, 1990; OKAмOTO et al., 1991); and 4) satellite cells proliferate by crushing (BISCHOFF, 1986b); 5) satellite cells are of myoblast origin (SNOW, 1977b; LIPTON and SCHULTZ, 1979; MALTin et al., 1983; BischofF, 1986a). NAtHANSON et al. $(1978,1980,1986)$ reported that myoblasts and fibroblasts transdifferentiated into chondroblasts. Besides, cartilage was not able to form from the skeletal muscle of a 5-week-old rat (data not shown), and there was a report that the number and the proliferating potential of satellite cells fall with aging (SCHULTZ and LIPTON, 1982; CAMPION, 1984). URIST et al. (1983) reported that the perivascular mesenchymal cells are the target of BMP. In this report, we observed several activated pericytes, although the vascular tissues were removed as much as possible. These cells might also be the origin of chondroblasts.

Dense bodies, presumably of lipid nature, were seen in almost all satellite cells and spindle-shaped cells soon after the beginning of the culture; these reduced by Day 3 (Figs. 1-3). These bodies thus seemed to have collected unnecessary organelles of the cells in the culture. Moreover, on Day 5, the cells in the crevices had dense bodies (Fig. 4). We suggest that these dense bodies of the satellite cells may serve as the marker of their differentiation into chondroblastic cells. In this context, one must take into consideration that similar lipid droplets generally tend to occur in various cells with the days of culturing.

There was hardly any cell division or cell death observed in the crevices, with cell organelles developing (Figs. 4, 5). Besides, cell process extended to the BMG on Day 7 (Fig. 6) and the crevices were filled with cartilage without any other cells on Day 10 (Fig. 8). It is considered that the crevices are probably a suitable place for the accumulation of a cartilage matrix, may supply a low oxygen environment (NILSEN, 1977; URIST et al., 1983) and are proper for the preservation of some factor released from the BMG (NATHANSON and HAY, 1980). These conditions may promote cartilage induction at the crevices.

In this report, we examined transdifferentiation using the BMG, paying especial attention to muscle satellite cells, the basement membrane and dense bodies. Under our conditions, appropriate cartilage formation was seen at an early stage of the culture. In this culture system, however, there were still several problems. That is, the BMG preparation in this experiment may contain other proteins besides BMP (SEYEDIN et al., 1985, 1986), and the muscle explants several types of cells. These problems must be cleared in future experiments.

\section{REFERENCES}

Amitani, K. and Y. Nakata: Studies on a factor responsible for new bone formation from osteosarcoma in mice. Calcif. Tiss. Res. 17: 139-150 (1975).

Bentz, H., R. M. Nathan, D. M. Rosen, R. M. Armstrong, A. Y. Thompson, P. R. Segarini, M. C. Mathews, J. R. DAsch, K. A. Piez and S. M. Seyedin: Purification and characterization of a unique osteoinductive factor from bovine bone. J. Biol. Chem. 264: 20805-20810 (1989).

Bischoff, R.: Proliferation of muscle satellite cells on intact myofibers in culture. Devel. Biol. 115: 129-139 (1986a).

: A satellite cell mitogen from crushed adult muscle. Devel. Biol. 115: 140-147 (1986b).

Campion, D. R.: The muscle satellite cell: a review. Int. Rev. Cytol. 87: 225-251 (1984).

Hughes, S. M. and H. M. Blau : Migration of myoblasts across basal lamina during skeletal muscle development. Nature 345: 350-353 (1990).

KaWAmura, M. and M. R. URIST: Growth factors, mitogens, cytokines, and bone morphogenetic protein in induced chondrogenesis in tissue culture. Devel. Biol. 130: 435-442 (1988).

Kelly, A. M. and S. I. ZaCk: The histogenesis of rat intercostal muscle. J. Cell Biol. 42: 135-153 (1969).

Kukita, A., L. Bonewald, D. Rosen, S. Seyedin, G. R. Mundy and G. D. Roodman: Osteoinductive factor inhibits formation of human osteoclast-like cells. Proc. Nat. Acad. Sci. USA 87: 3023-3026 (1990).

LANDEsman, R. and A. H. REDDI: Chemotaxis of muscle-derived mesenchymal cells to bone-inductive proteins of rat. Calcif. Tiss. Int. 39: 259-262 (1986). 
Lipton, B. H. and E. Schultz: Developmental fate of skeletal muscle satellite cells. Science 205: 1292-1294 (1979).

Lopashov, G. V.: Levels in stabilization of cell differentiation and its experimental transformation. Differentiation 9: 131-137 (1977).

Luyten, F. P., N. S. Cunningham, S. Ma, N. Muthukumaran, R. G. Hammonds, W. B. Nevins, W. I. Wood and A. H. Reddi: Purification and partial amino sequence of osteogenin, a protein initiating bone differentiation. J. Biol. Chem. 264: 13377-13380 (1989).

Maltin, C. A.: Observations of satellite cells in rat skeletal muscle incubated in vitro. Cell Tiss. Res. 245: 177-181 (1986).

Maltin, C. A., J. B. Harris and M. J. Cullen: Regeneration of mammalian skeletal muscle following the injection of the snake-venom toxin, taipoxin. Cell Tiss. Res. 232: 565-577 (1983)

Nathanson, M. A.: Transdifferentiation of skeletal muscle into cartilage: Transformation or differentiation? Curr. Top. Devel. Biol. 20: 39-62 (1986).

Nathanson, M. A. and E. D. HAY: Analysis of cartilage differentiation from skeletal muscle grown on bone matrix. I. Ultrastructural aspects. Devel. Biol. 78: 301331 (1980).

Nathanson, M. A., S. R. Hilfer and R. L. Searls: Formation of cartilage by non-chondrogenic cell types. Devel. Biol. 64: 99-117 (1978).

NiLSEN, R.: Electron microscopy of induced heterotopic bone formation in guinea pigs. Arch. Oral Biol. 22: 485493 (1977).

-: Electronmicroscopic study of mineralization in induced heterotopic bone formation in guinea pigs. Scand. J. Dent. Res. 88: 340-347 (1980).

NoGami, H. and M. R. URIST: Substrata prepared from bone matrix for chondrogenesis in tissue culture. J. Cell Biol. 62: 510-519 (1974).

OKamoto, Y., Y. Horisaka, N. Matsumoto, Y. YoshimuRa, J. KaWAda, K. Yamashita and T. TAKagi: Muscle tissue reactions to implantation of bone matrix gelatin. Clin. Orthoped. 263: 242-253 (1991).

ONTELL, M.: Neonatal muscle: an electron microscopic study. Anat. Rec. 189: 669-690 (1977).

Ontell, M. and K. KozeKa: The organogenesis of murine striated muscle: a cytoarchitectural study. Amer. J. Anat. 171: 133-148 (1984).

REDdi, A. H. and W. A. Anderson: Collagenous bone matrix-induced endochondral ossification and hemopoiesis. J. Cell Biol. 69: 557-572 (1976).

Sampath, T. K., N. Muthukumaran and A. H. Redd: Isolation of ostogenin, an extracellular matrixassociated, bone-inductive protein, by heparin affinity chromatography. Proc. Nat. Acad. Sci. USA 84: 71097113 (1987).

Schultz, E. S. and B. H. Lipton: Skeletal muscle satellite cells: changes in proliferation potential as a function of age. Mechanis. Age. Devel. 20: 377-383 (1982).

Seyedin, S. M., T. C. Thomas, A. Y. Thompson, D. M. Rosen and K. A. Piez: Purification and characteriza- tion of two cartilage-inducing factors from bovine demineralized bone. Proc. Nat. Acad. Sci. USA 82: 2267-2271 (1985).

Seyedin, S. M., A. O. Thompson, H. Bentz, D. M. Rosen, J. M. McPherson, A. Conti, N. R. Siegel, G. R. Galluppi and K. A. PIEz: Cartilage-inducing factorA. Apparent identity to transforming growth factor- $\beta$. J. Biol. Chem. 261: 5693-5695 (1986).

SNow, M. H.: Myogenic cell formation in regenerating rat skeletal muscle injured by mincing. I. A fine structural study. II. An autoradiographic study. Anat. Rec. 188: 181-200, 201-218 (1977a, b).

Somerman, M. J., M. A. Nathanson, J. J. Sauk and B. Manson: Human dentin matrix induces cartilage formation in vitro by mesenchymal cells derived from embryonic muscle. J. Dent. Res. 66: 1551-1558 (1987).

Takaoka, K., H. Yoshikawa, N. Shimizu, K. Ono, K. Amitani, Y. Nakata and Y. Sakamoto: Purification of a bone-inducing substance (osteogenic factor) from a murine osteosarcoma. Biomed. Res. 2: 446-471 (1981).

URIST, M. R.: Bone formation by autoinduction. Science 150: 893-899 (1965).

Urist, M. R., R. J. Delange and G. A. M. Finerman: Bone cell differentiation and growth factors. Science 220: 680-686 (1983).

Urist, M. R., Y. K. Huo, A. G. Brownell, M. M. HoHL, J. Buyske, A. Lietze, P. Tempst, M. Hunkapiller and R. J. DeLANGe: Purification of bovine bone morphogenetic protein by hydroxyapatite chromatography. Proc. Nat. Acad. Sci. USA 81: 371-375 (1984).

Urist, M. R., H. Iwata, P. L. Ceccotti, R. L. Dorfman, S. D. Boyd, R. M. McDowell and C. Chien: Bone morphogenesis in implants of insoluble bone gelatin. Proc. Nat. Acad. Sci. USA 70: 3511-3515 (1973).

Urist, M. R., Y. Terashima, M. Nakagawa and C. STamos: Cartilage tissue differentiation from mesenchymal cells derived from mature muscle in tissue culture. In Vitro 14: 697-706 (1978).

Vukicevic, S., F. P. Luyten and A. H. Reddi: Stimulation of the expression of osteogenic and chondrogenic phenotypes in vitro by osteogenin. Proc. Nat. Acad. Sci. USA 86: 8793-8797 (1989).

-: Osteogenin inhibits proliferation and stimulates differentiation in mouse osteoblast-like cells (MC3T3-E1). Biochem. Biophys. Res. Commum. 166: 750-756 (1990).

Wang, E. A., V. Rosen, J. S. D'Alessandro, M. Bauduy, P. Cordes, T. Harada, D. I. Israel, R. M. Hewick, K. M. Kerns, P. LaPan, D. P. Luxenberg, D. MuQuaid, I. K. Moutsatsos, J. Nove and J. M. WozNEY: Recombinant human bone morphogenetic protein induces bone formation. Proc. Nat. Acad. Sci. USA 87: 2220-2224 (1990).

Wozney, J. M., V. Rosen, A. J. Celeste, L. M. Mitsock, M. J. Whitters, R. M. KRIz, R. M. HewiCK and E. A. W ANG: Novel regulators of bone formation: molecular clones and activities. Science 242: 1528-1534 (1988). 
Dr. Yasuyuki HoRISAKA

Department of Removable Prosthodontics

Tokushima University School of Dentistry

3-18-15 Kuramoto-cho, Tokushima

770 Japan

堀 坂 寧介

770 徳島市蔵本町 3-18-15

徳島大学歯学部

歯科補緅学第一講座 